\title{
Analytical development of a binuclear oxo-manganese complex bio-inspired on oxidase enzyme for doping control analysis of acetazolamide
}

\author{
Wesley B.S. Machini, Marcos F.S. Teixeira* \\ Department of Chemistry and Biochemistry, Faculty of Science and Technology, São Paulo State University (UNESP), Roberto Simonsen St, 305, CEP 19060-900 \\ Presidente Prudente, SP, Brazil
}

\section{A R T I C L E I N F O}

\section{Article history:}

Received 26 September 2015

Received in revised form

10 December 2015

Accepted 12 December 2015

Available online 15 December 2015

Keywords:

Bio-inspired sensor

Biomimetic

Doping analysis

\begin{abstract}
A B S T R A C T
A bio-inspired electrochemical sensor using a binuclear oxo-manganese complex was evaluated and applied in the detection of a substance associated with doping in sports: acetazolamide (ACTZ). Investigation was made of the influence of different experimental variables on the electrocatalytic oxidation of ACTZ by the bio-inspired sensor, such as $\mathrm{pH}$ and interfering species. The bio-inspired sensor showed the best response in the range from $5.00 \times 10^{-9}$ to $7.00 \times 10^{-8} \mathrm{~mol} \mathrm{~L}^{-1} \mathrm{ACTZ}$, with a linear range from $5.00 \times 10^{-9}$ to $2.50 \times 10^{-8} \mathrm{~mol} \mathrm{~L}^{-1}$ and a detection limit of $4.76 \times 10^{-9} \mathrm{~mol} \mathrm{~L}^{-1}$. The sensor exhibited characteristics similar to the Michaelis-Menten model of an enzymatic electrode, due to the use of a multinucleated complex of manganese with $\mu$-oxo units, which was able to mimic the properties of enzymes with manganese as a cofactor in their composition, such as Mn-containing oxidase. The determination of ACTZ with the bio-inspired sensor was evaluated using three different synthetic biological fluids (plasma, saliva, and urine), demonstrating its viability for use with real samples. The analysis of ACTZ in real urine samples using the bio-inspired sensor, simulating the method adopted by the World Anti-Doping Agency, which revealed viable, suggesting a new and promising platform to be used in these analysis.
\end{abstract}

(c) 2015 Elsevier B.V. All rights reserved.

\section{Introduction}

The advent of the use of substances that enhance the performance of athletes to give them competitive advantage, whether as "drugs" or other highly purified and potent compounds, has resulted in systematic screening to detect and prevent the use of such substances (Fraser, 2004). Since 2004, the World Anti-Doping Code and the World Anti-Doping Agency (WADA) have listed substances and methods prohibited in sport, both within and outside competition (WADA, 2014a; Mazzoni et al., 2011).

Diuretics were first banned in sport in 1988 due to their use by athletes to eliminate water from the body and cause a rapid weight loss in order to comply with weight limits in sports such as boxing, judo, and weightlifting, as well as to mask the administration of other doping agents by reducing their concentrations in urine. Acetazolamide (ACTZ), an inhibitor of the carbonic anhydrase enzyme, is used clinically either alone or in combination with other drugs to treat glaucoma (Kaur et al., 2002), various forms of epilepsy (Reiss and Oles, 1996), and a range of other

\footnotetext{
* Corresponding author.

E-mail address: funcao@fct.unesp.br (M.F.S. Teixeira).
}

conditions (Aurora et al., 2012; Brayfield, 2014; Low et al., 2012; Wall et al., 2014). Despite having clinical applications, its use in athletes can cause arrhythmia, dehydration, hypotension, and renal insufficiency. The literature describes different methods for the detection and quantification of ACTZ, including chromatography (Chapron and White, 1984; Ichikawa et al., 1998; Moratal et al., 1992; Wallace et al., 1977; Zarghi and Shafaati, 2002), enzymatic assays (Greene and Kenny, 1992), biosensing (Jeronimo et al., 2005), spectrophotometry (Almeida et al., 2013; Khamis et al., 1993; Walash et al., 2010), and electrochemistry (Debalugera et al., 1994; Fogg and Ghawji, 1988; Gholivand and Parvin, 2011; Khodadadian and Ahmadi, 2010; Shakibaian and Parvin, 2012).

The synthesis of biomimetic enzymes enables the reproduction of specific characteristics of biological molecules. The design of metallic complexes for the modeling of metallo-enzyme active sites is a fruitful strategy that can be used to obtain fundamental information concerning mechanisms involving biological molecules (Rebilly et al., 2015).

Due their similar catalytic, kinetic, and structural characteristics as the active sites of enzymes that have manganese as a cofactor in their composition (Christou, 1989; Pecoraro et al., 1994; Renger, 1987; Wieghardt, 1989, 1994), multinucleated complexes 
of manganese with $\mu$-oxo units have been studied and applied in the development of bio-inspired or biomimetic sensors (Franzoi et al., 2009; Machini and Teixeira, 2014, 2015; Santos et al., 2009). Compared to the use of biosensors, bio-inspired sensors exhibit excellent catalytic and kinetic properties, as well as high selectivity and sensitivity. Their use enables simplification of the system, decreasing the need to control the reaction conditions (such as $\mathrm{pH}$ and temperature), minimizing interfering species, and eliminating extraction and purification procedures. There is therefore considerable interest in developing this research area.

In this way, the present work describes the development and application of an electrochemical sensor using a bio-inspired binuclear oxo-manganese complex based on the oxidase enzyme for the detection of a substance (acetazolamide) used in doping and prohibited by the WADA, envisaging the application of the technique to real samples.

\section{Experimental}

\subsection{Reagents and solutions}

The supporting electrolyte used in all the experiments was $0.1 \mathrm{~mol} \mathrm{~L}^{-1}$ acetate buffer, with the $\mathrm{pH}$ adjusted by adding concentrated $\mathrm{HCl}$ or $\mathrm{NaOH}$. An acetazolamide standard solution $\left(0.10 \mathrm{mmol} \mathrm{L}^{-1}\right)$ was prepared by dissolution of an appropriate amount of the compound in acetate buffer. Graphite powder $(>20 \mu \mathrm{m})$ and high purity mineral oil were used in the preparation of the bio-inspired sensor. All the reagents were from Aldrich. The biomimetic synthesis is described in the Supplementary material.

\subsection{Electrochemical behavior and analytical performance of the bio- inspired sensor}

All voltammetric measurements were carried out at $25^{\circ} \mathrm{C}$ in a $20 \mathrm{~mL}$ temperature-controlled glass cell with a three-electrode configuration: the bio-inspired sensor based on the binuclear oxomanganese(III,IV)-phenanthroline complex was used as the working electrode, a saturated calomel electrode (SCE) was used as the reference electrode, and the auxiliary electrode was a platinum wire. These measurements were performed using a $\mu$-AUTOLAB type III potentiostat/galvanostat (Eco Chimie) controlled with GPES v. 4.9 software.

The bio-inspired sensor was prepared by mixing $10 \%(\mathrm{w} / \mathrm{w})$ of the $\left[\mathrm{Mn}^{\mathrm{III} / \mathrm{IV}}(\mu-\mathrm{O})(\text { phen })_{2}\right]_{2}\left(\mathrm{ClO}_{4}\right)_{3}$ complex with $60 \%(\mathrm{w} / \mathrm{w})$ of graphite power and subsequently adding $30 \%(\mathrm{w} / \mathrm{w})$ of mineral oil (Svancara et al., 2009). This material was packed into an electrode body consisting of a cylindrical plastic tube ( $6 \mathrm{~mm}$ i.d.) fitted with a stainless steel rod that provided the external electrical contact.

The electrochemical behavior of the bio-inspired sensor was studied using cyclic voltammetry in the potential range from 0.0 to $1.2 \mathrm{~V}$, with different scan rates, in $0.1 \mathrm{~mol} \mathrm{~L}^{-1}$ acetate buffer solution. For each measurement, 3 successive cycles were carried out to ensure signal stabilization and the third cycle was kept as the result.

The electrochemical performance of the sensor for detection of ACTZ was evaluated by the addition of analytical standards to the electrochemical cell.

\subsection{Application of the sensor using synthetic biological fluid samples}

The application of the bio-inspired sensor in the determination of ACTZ was investigated using synthetic plasma, saliva, and urine samples (Laube et al., 2001; Liu et al., 2006). The samples were deliberately contaminated with $1.0 \times 10^{-4} \mathrm{~mol} \mathrm{~L}-1$ ACTZ, and the $\mathrm{pH}$ was adjusted to 5.6. The measurements were made in

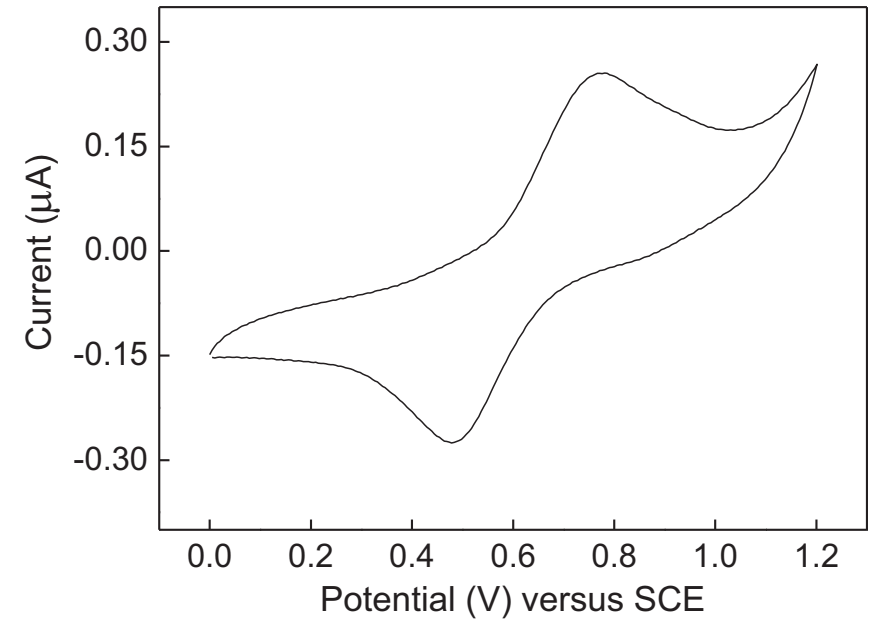

Fig. 1. Cyclic voltammogram for the bio-inspired sensor in $0.1 \mathrm{~mol} \mathrm{~L}^{-1}$ acetate buffer ( $\mathrm{pH} 4.7$ ), using a scan rate of $25 \mathrm{mV} \mathrm{s}^{-1}$ in the potential range from 0.0 to $1.2 \mathrm{~V}$ vs. SCE.

$0.1 \mathrm{~mol} \mathrm{~L}^{-1}$ acetate buffer solution ( $\mathrm{pH} 5.6$ ) using cyclic voltammetry in the potential range from 0.0 to $1.2 \mathrm{~V} v s$. SCE, with a scan rate of $25 \mathrm{mV} \mathrm{s}^{-1}$. After recording cyclic voltammograms in the absence of ACTZ, an aliquot of the spiked sample was added to the electrochemical cell to give a final concentration of $3.0 \times 10^{-7} \mathrm{~mol} \mathrm{~L}^{-1} \mathrm{ACTZ}$, followed by multiple standard additions of acetazolamide.

\subsection{Collection and treatment of a human urine sample for doping control analysis}

The electroanalytical application of the bio-inspired sensor in doping control analysis was investigated using the determination of ACTZ in a human urine sample, simulating the method adopted by WADA (2012).

A volunteer sportsman, 24 years old, was treated with one tablet of Diamox ${ }^{\mathrm{B}}$ containing $250 \mathrm{mg}$ of ACTZ. After $6 \mathrm{~h}$, a urine sample was collected in a sterilized plastic container and stored in a freezer at $-20^{\circ} \mathrm{C}$. A blank urine sample was collected before administration of the drug to the volunteer. In the laboratory, the urine samples were treated prior to analysis, as described in Supplementary material.

The bio-inspired sensor was tested for the doping control analysis of acetazolamide using multiple standard additions to the collected urine sample. The same conditions used in the electrochemical analysis of the synthetic samples were employed in the doping control experiment.

\section{Results and discussion}

\subsection{Electrochemical properties of the bio-inspired sensor}

Firstly, the electrochemical behavior of the bio-inspired sensor based on the binuclear oxo-manganese(III,IV)-phenanthroline complex was investigated by cyclic voltammetry in $0.1 \mathrm{~mol} \mathrm{~L}^{-1}$ acetate buffer solution ( $\mathrm{pH} 4.7)$, in the presence of molecular oxygen as an inhibitor of the activity of the electrochemical sensor (see Supplementary material).

The cyclic voltammograms (Fig. 1) revealed a quasi-reversible system with one redox process $\left(E_{p a}=0.795 \mathrm{~V}\right.$ and $E_{p c}=0.444 \mathrm{~V} v$ s. $\mathrm{SCE})$, with peak-to-peak separation $\left(\Delta E_{p}\right)$ and formal potential $\left(E_{p / 2}\right)$ of $0.351 \mathrm{~V}$ and $0.620 \mathrm{~V} v s$. SCE, respectively, attributed to the $\mathrm{Mn}^{\mathrm{IV} / \mathrm{IV}} / \mathrm{Mn}^{\mathrm{III} / \mathrm{IV}}$ redox couple: 


$$
\begin{aligned}
& {\left[\mathrm{Mn}^{\mathrm{IV}}(\mu-\mathrm{O})_{2} \mathrm{Mn}^{\mathrm{IV}}\right]_{\text {(surface) }}^{4+}+1 \mathrm{e}^{-}+\mathrm{H}_{2} \mathrm{O}} \\
& \quad \rightarrow\left[\mathrm{Mn}^{\mathrm{III}}(\mu-\mathrm{O})(\mu-\mathrm{OH}) \mathrm{Mn}^{\mathrm{IV}}\right]_{\text {(surface) }}^{4+}+\mathrm{OH}^{-}
\end{aligned}
$$

The surface concentration of electroactive species was estimated from the background-corrected electric charge $(Q)$ obtained for anodic peaks in cyclic voltammograms acquired at a slow scan rate $\left(5 \mathrm{mV} \mathrm{s}^{-1}\right)$ (Bard and Faulkner, 2001). The concentration of electroactive species was found to be $4.5 \times 10^{-8} \mathrm{~mol} \mathrm{~cm}^{-2}$.

\subsection{Electrochemical response of acetazolamide at the bio-inspired sensor}

Fig. 2 shows the cyclic voltammograms for the bio-inspired sensor in the absence of ACTZ and in the presence of $2.50 \times 10^{-7} \mathrm{~mol} \mathrm{~L}^{-1}$, $2.50 \times 10^{-6} \mathrm{~mol} \mathrm{~L}^{-1}$, and $5.00 \times 10^{-6} \mathrm{~mol} \mathrm{~L}^{-1}$ concentrations of the compound, where it can be seen that the anodic and cathodic peak currents increased with increasing ACTZ concentration.

The effect of the potential scan rate (between 5 and $200 \mathrm{mV} \mathrm{s}^{-1}$ ) on the voltammetric response in the electrooxidation of ACTZ was investigated using $0.1 \mathrm{~mol} \mathrm{~L}^{-1}$ acetate buffer containing $1.00 \times 10^{-6} \mathrm{~mol} \mathrm{~L}^{-1}$ ACTZ. The anodic and cathodic peak currents varied linearly with the square root of the scan rate (Supplementary material), suggesting that the oxidation of ACTZ followed a diffusion-controlled mechanism. For scan rates over $50 \mathrm{mV} \mathrm{s}^{-1}$, small decreases of the anodic and cathodic peak currents were observed, indicating that at high scan rates there was a limitation on the kinetics of the reaction between ACTZ and $\mathrm{Mn}^{\mathrm{IV}}(\mu-\mathrm{O})_{2} \mathrm{Mn}^{\mathrm{IV}}$ on the electrode surface.

The influence of $\mathrm{pH}$ on the voltammetric response of the bioinspired sensor in the determination of ACTZ was evaluated using $0.1 \mathrm{~mol} \mathrm{~L}^{-1}$ acetate buffer (pH 3.8-5.6) containing $1.00 \times$ $10^{-6} \mathrm{~mol} \mathrm{~L}^{-1}$ ACTZ. The linear portion of the plot of formal potential $\left(\frac{\left[E_{p a}+E_{p c}\right]}{2}\right)$ against $\mathrm{pH}$ presented two distinct regions (Supplementary material). The results indicated that between $\mathrm{pH} 3.8$ and 4.4, the acetazolamide was electrochemically reduced in a $1 \mathrm{H}^{+}$and $2 \mathrm{e}^{-}$reaction (slope: $34 \mathrm{mV} \mathrm{pH}^{-1}$ ). This behavior was in agreement with the reported voltammetric behavior of acetazolamide (Shakibaian and Parvin, 2012). Interestingly, a slope value of $-51 \mathrm{mV} \mathrm{pH}^{-1}$ was obtained in the $\mathrm{pH}$ range 4.7-5.6. This slope corresponded to a redox process involving one proton and one electron. The equilibrium between $\mathrm{Mn}^{\mathrm{III}} \mathrm{Mn}^{\mathrm{IV}}$ centers can then be represented by:

$$
\begin{aligned}
& {\left[\operatorname{Mn}^{\mathrm{III}}(\mu-\mathrm{O})(\mu-\mathrm{OH}) \mathrm{Mn}^{\mathrm{IV}}\right]_{\text {(surface) }}^{4+}} \\
& \quad \rightarrow\left[\mathrm{Mn}^{\mathrm{IV}}(\mu-\mathrm{O})_{2} \mathrm{Mn}^{\mathrm{IV}}\right]_{(\text {surface) }}^{4+}+1 \mathrm{H}^{+}+1 \mathrm{e}^{-}
\end{aligned}
$$

This behavior is attributed to proton coupled electron transfer (PCET), which is commonly applied to oxo-manganese complexes due to their participation in the photosystem II mechanism (Machini and Teixeira, 2014, 2015; Meyer et al., 2007; Rivalta et al., 2012; Sproviero et al., 2006). According to the mechanism proposed by Gholivand and Parvin (2011) for ACTZ electrooxidation at pH below 7.0, the bio-inspired sensor promoted ACTZ electrooxidation via a catalytic mechanism whereby one core of $\mathrm{Mn}^{\mathrm{III}} \mathrm{Mn}^{\mathrm{IV}}$ was electrochemically

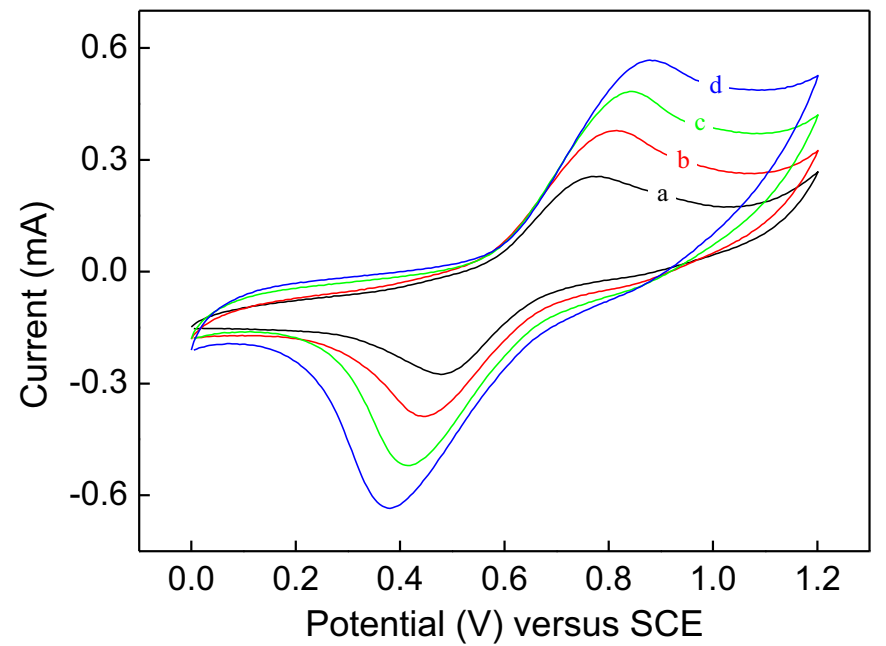

Fig. 2. Cyclic voltammogram for the bio-inspired sensor in $0.1 \mathrm{~mol} \mathrm{~L}^{-1}$ acetate buffer ( $\mathrm{pH} 4.76$ ) using a potential range from 0.0 to $1.2 \mathrm{~V} \mathrm{vs}$. SCE, at $25 \mathrm{mV} \mathrm{s}^{-1}$, in the absence of ACTZ (a) and in the presence of (b) $2.50 \times 10^{-7} \mathrm{~mol} \mathrm{~L}^{-1}$, (c) $2.50 \times 10^{-6} \mathrm{~mol} \mathrm{~L}^{-1}$, and (d) $5.00 \times 10^{-6} \mathrm{~mol} \mathrm{~L}^{-1} \mathrm{ACTZ}$

oxidized to $\mathrm{Mn}^{\mathrm{IV}} \mathrm{Mn}^{\mathrm{IV}}$ at the electrode surface. The chemical step can therefore be represented by the following equation:

From analysis of the degree of reversibility $\left(\Delta E_{p}=E_{p a}-E_{p c}\right)$ of the active material in the presence ACTZ (Supplementary material), it was decided to select the $\mathrm{pH}$ that showed the least effect on the peak-to-peak separation distance. The subsequent experiments were therefore performed using $0.1 \mathrm{~mol} \mathrm{~L}^{-1}$ acetate buffer solution at $\mathrm{pH}$ 5.6.

\subsection{Analytical performance}

After optimizing the operating parameters, cyclic voltammetry measurements were performed in $0.1 \mathrm{~mol} \mathrm{~L}^{-1}$ acetate buffer solution ( $\mathrm{pH}$ 5.6), varying the initial concentration from $5.0 \times 10^{-8} \mathrm{~mol} \mathrm{~L}^{-1}$ to $7.5 \times 10^{-7} \mathrm{~mol} \mathrm{~L}^{-1} \mathrm{ACTZ}$ (Fig. 3a). The plot of anodic peak current against the concentration of ACTZ (Fig. 3b) showed two linear ranges, between $5.00 \times 10^{-8} \mathrm{~mol} \mathrm{~L}^{-1}$ and $3.50 \times 10^{-7} \mathrm{~mol} \mathrm{~L}^{-1}$, and between $3.50 \times 10^{-7} \mathrm{~mol} \mathrm{~L}-1$ and $7.50 \times 10^{-7} \mathrm{~mol} \mathrm{~L}^{-1}$, which could be described by the linear regression Eqs. (3) and (4), respectively.

$$
\begin{aligned}
\Delta I_{p a}(\mathrm{~mA}) & =-0.0017+0.3865[\mathrm{ACTZ}] \mu \mathrm{mol} \mathrm{L}^{-1} \\
& \rightarrow(n=7, r=0.9995)
\end{aligned}
$$

$\Delta I_{p a}(\mathrm{~mA})=0.0279+0.3038[\mathrm{ACTZ}] \mu \mathrm{mol} \mathrm{L}^{-1}$

$$
\rightarrow(n=9, r=0.9992)
$$

Another analytical curve was constructed using linear scanning voltammetric measurements with different concentrations of ACTZ. The linear voltammograms were obtained in $0.1 \mathrm{~mol} \mathrm{~L}^{-1}$ acetate buffer ( $\mathrm{pH}$ 5.6), varying the ACTZ concentration from $5.00 \times 10^{-9} \mathrm{~mol} \mathrm{~L}^{-1}$ to $7.00 \times 10^{-8} \mathrm{~mol} \mathrm{~L}^{-1}$ (Fig. 3c). This proce-<smiles>CC(=O)Nc1nnc(S(N)(=O)=O)s1</smiles> 

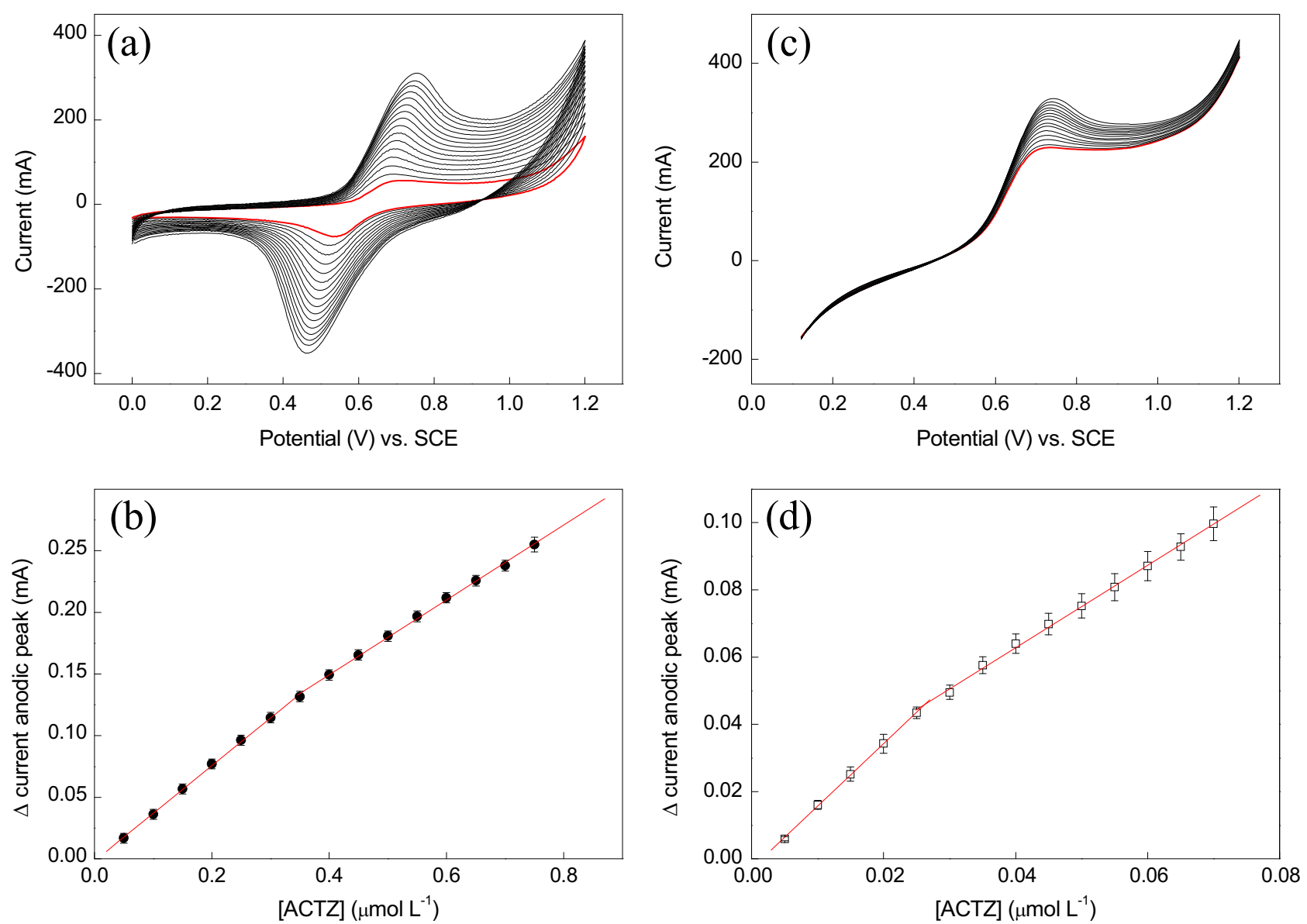

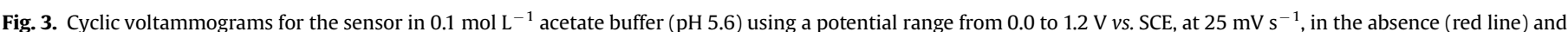

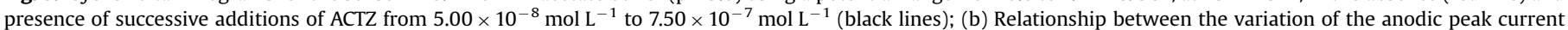

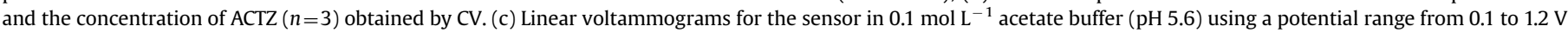

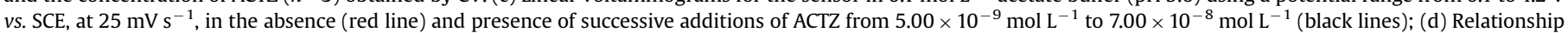
between the variation of the anodic peak current and the concentration of ACTZ $(n=3)$ obtained by LV.

dure resulted in a better analytical response than obtained by cyclic voltammetry. As shown in the analytical curve (Fig. 3d), two linear ranges were once again observed, between $5.00 \times 10^{-9} \mathrm{~mol} \mathrm{~L}^{-1}$ and $2.50 \times 10^{-8} \mathrm{~mol} \mathrm{~L}^{-1} \mathrm{ACTZ}$, and between $2.50 \times 10^{-8} \mathrm{~mol} \mathrm{~L}^{-1}$ and $7.00 \times 10^{-8} \mathrm{~mol} \mathrm{~L}^{-1} \mathrm{ACTZ}$, described by linear regression Eqs. (5) and (6), respectively.

$$
\begin{aligned}
\Delta I_{p a}(\mathrm{~mA}) & =-0.003+1.86[\mathrm{ACTZ}] \mu \mathrm{mol} \mathrm{L}^{-1} \\
& \rightarrow(n=5, r=0.9998)
\end{aligned}
$$

$$
\begin{aligned}
\Delta I_{p a}(\mathrm{~mA}) & =0.0014+1.23[\mathrm{ACTZ}] \mu \mathrm{mol} \mathrm{L}^{-1} \\
& \rightarrow(n=10, r=0.9991)
\end{aligned}
$$

The lowest linear ranges were used to determine the limits of quantification (ten times the blank signal/slope) and detection (three times the blank signal/slope) (McNaught and Wilkinson, 1997). Table 1 summarizes the results obtained for the determination of ACTZ by the bio-inspired sensor, using the two different electrochemical techniques, and compares these values with those for electrochemical sensors for ACTZ reported in the literature. It can be seen that the proposed sensor provided better results than the earlier methods for the oxidation of ACTZ, demonstrating its high efficiency and sensitivity.

The possible influence of other electroactive compounds on the determination of ACTZ by the bio-inspired sensor was investigated using seven different substances: ascorbic acid, citric acid, uric acid, caffeine, dipyrone, glucose, and paracetamol. The studies were conducted using cyclic voltammetry in $0.1 \mathrm{~mol} \mathrm{~L}^{-1}$ acetate buffer ( $\mathrm{pH}$ 5.6) with a fixed concentration of $1.00 \times 10^{-6} \mathrm{~mol} \mathrm{~L}^{-1}$ ACTZ and a fixed concentration of $1.00 \times 10^{-6} \mathrm{~mol} \mathrm{~L}^{-1}$ of the possible interferent. The analyzed components were not considered to interfere when the relative error in the measured current was less than $5 \%$ (Supplementary material). The greatest interferences in the ACTZ analytical signal were caused by ascorbic acid, citric acid, and dipyrone. However, none of the effects exceeded $5 \%$.

\subsection{Evaluation of biomimetic characteristics}

The biomimetic properties of the sensor were reflected in a response plot that showed a hyperbolic profile for acetazolamide concentrations between $1.00 \times 10^{-6} \mathrm{~mol} \mathrm{~L}^{-1}$ and $1.00 \times 10^{-5} \mathrm{~mol} \mathrm{~L}^{-1}$ (Supplementary material). In such cases, the reaction rate increases with increasing substrate concentration and must asymptotically approach the saturation rate that is directly proportional to the total biomimetic material concentration (Boni et al., 2010; Ruy et al., 2014). Similarly, for concentrations higher than $5.00 \times 10^{-6} \mathrm{~mol} \mathrm{~L}^{-1}$, the proposed bio-inspired sensor showed marked deviation from linearity, which could be attributed to the maximum saturation of the electrocatalytic sites on the electrode surface.

Given the ability of the multinucleated oxo-manganese complexes to mimic enzyme active sites, the biomimetic properties of the bio-inspired sensor were subsequently analyzed according to 
Table 1

Analytical features of different sensors and electrochemical techniques used for the determination of ACTZ.

\begin{tabular}{|c|c|c|c|c|}
\hline Material & Bio-inspired & & GNP-MCPE & MISPE \\
\hline $\begin{array}{l}\text { Voltammetric } \\
\text { technique }\end{array}$ & Cyclic voltammetry & Linear voltammetry & Differential pulse voltammetry & Differential pulse voltammetry \\
\hline Response range & $5.00 \times 10^{-8}-7.500^{-7} \mathrm{~mol} \mathrm{~L}^{-1}$ & $5.00 \times 10^{-9}-7.00 \times 10^{-8} \mathrm{~mol} \mathrm{~L}^{-1}$ & $1.00 \times 10^{-8}-8.00 \times 10^{-5} \mathrm{~mol} \mathrm{~L}^{-1}$ & $\begin{array}{l}9.00 \times 10^{-7}- \\
8.10 \times 10^{-5} \mathrm{~mol} \mathrm{~L}^{-1}\end{array}$ \\
\hline Linear range & $\begin{array}{l}5.00 \times 10^{-8}- \\
3.50 \times 10^{-7} \mathrm{~mol} \mathrm{~L}^{-1}\end{array}$ & $\begin{array}{l}5.00 \times 10^{-9}- \\
2.50 \times 10^{-8} \mathrm{~mol} \mathrm{~L}^{-1}\end{array}$ & $1.00 \times 10^{-8}-8.00 \times 10^{-5} \mathrm{~mol} \mathrm{~L}^{-1}$ & $\begin{array}{l}9.00 \times 10^{-7}- \\
8.10 \times 10^{-5} \mathrm{~mol} \mathrm{~L}^{-1}\end{array}$ \\
\hline Limit of quantification & $4.41 \times 10^{-8} \mathrm{~mol} \mathrm{~L}^{-1}$ & $1.59 \times 10^{-8} \mathrm{~mol} \mathrm{~L}^{-1}$ & $2.40 \times 10^{-8} \mathrm{~mol} \mathrm{~L}^{-1}$ & $9.00 \times 10^{-7} \mathrm{~mol} \mathrm{~L}^{-1}$ \\
\hline $\begin{array}{l}\text { Limit of detection } \\
\text { Reference }\end{array}$ & $\begin{array}{l}1.32 \times 10^{-8} \mathrm{~mol} \mathrm{~L}^{-1} \\
\text { This work }\end{array}$ & $4.76 \times 10^{-9} \mathrm{~mol} \mathrm{~L}^{-1}$ & $\begin{array}{l}7.10 \times 10^{-9} \mathrm{~mol} \mathrm{~L}^{-1} \\
\text { (Gholivand and Parvin, 2011) }\end{array}$ & $\begin{array}{l}2.70 \times 10^{-7} \mathrm{~mol} \mathrm{~L}^{-1} \\
\text { (Khodadadian and Ahmadi, 2010) }\end{array}$ \\
\hline
\end{tabular}

GNP-MCPE : gold nanoparticles modified carbon paste electrode; MISPE : molecularly imprinted polymer electrode.

Table 2

Michaelis-Menten kinetic parameters applied to the bio-inspired sensor based on binuclear oxo-manganese(III,IV)-phenanthroline complex.

\begin{tabular}{|c|c|c|c|c|}
\hline Method & $K_{M}$ & $k_{\text {cat }}$ & $k_{s}$ & $k_{e}^{\prime}$ \\
\hline Lineweaver-Burke & 1.148 & 0.282 & 2.456 & 0.011 \\
\hline Eadie-Hofstee & 1.204 & 0.286 & 2.375 & 0.011 \\
\hline Hanes-Woolf & 1.241 & 0.287 & 2.313 & 0.010 \\
\hline
\end{tabular}

$K_{M}^{q p p}: \mu \mathrm{mol} \mathrm{L}^{-1} ; k_{\text {cat }}: \mathrm{s}^{-1} ; k_{\mathrm{s}}\left(10^{5}\right):(\mathrm{mol} \mathrm{L})^{-1} \mathrm{~s}^{-1} ; k_{e}^{\prime}: \mathrm{cm} \mathrm{s}^{-1}$.

the Michaelis-Menten model. A possible mechanism can be described as follows:

$$
\begin{gathered}
{\left[\mathrm{Mn}^{\mathrm{IV}}(\mu \mathrm{O})_{2} \mathrm{Mn}^{\mathrm{IV}}\right]_{(s)}+\mathrm{ACTZ}_{(\text {red })} \underset{k_{-1}}{k_{1}}} \\
{\left[\left(\mathrm{Mn}^{\mathrm{IV}}(\mu \mathrm{O})_{2} \mathrm{Mn}^{\mathrm{IV}}\right)-\left(\mathrm{ACTZ}_{(\text {red })}\right)\right]_{(\text {adduct })}} \\
{\left[\left(\mathrm{Mn}^{\mathrm{IV}}(\mu \mathrm{O})_{2} \mathrm{Mn}^{\mathrm{IV}}\right)-\left(\mathrm{ACTZ}_{(\text {red })}\right)\right]} \\
\stackrel{k_{\text {cat }}}{\rightarrow}\left[\mathrm{Mn}^{\mathrm{III}}(\mu \mathrm{O})(\mu \mathrm{OH}) \mathrm{Mn}^{\mathrm{IV}}\right]_{(s)}+\mathrm{ACTZ}_{(\text {ox })}
\end{gathered}
$$

Starting from the Michaelis-Menten rearrangement equation (Eq. (9)), applied to ACTZ for steady-state catalytic current (iSSC) (Lyons et al., 1994, 1998), the kinetic parameters were obtained in three different ways, using the Lineweaver-Burke, Eadie-Hofstee, and Hanes-Woolf approaches (Supplementary material).

$i_{S S C}=\frac{n F A \Gamma k_{c a t}[\mathrm{ACTZ}]}{K_{M}^{a p p}+[\mathrm{ACTZ}]}=\frac{i_{\max }[\mathrm{ACTZ}]}{K_{M}^{a p p}+[\mathrm{ACTZ}]}$

In Eq. (9), $n$ is the number of electrons involved in the catalytic reaction, $K_{M}^{a p p}\left(\mathrm{~mol} \mathrm{~L}^{-1}\right)$ is the apparent Michaelis-Menten constant, $A\left(\mathrm{~cm}^{2}\right)$ is the electrode area, $\Gamma\left(\mathrm{mol} \mathrm{cm}{ }^{-2}\right)$ is the electroactive concentration on the electrode surface, $k_{\text {cat }}$ is the catalytic rate constant, $i_{\max }$ is the maximum catalytic current $\left(i_{\text {max }}=n F A \Gamma k_{\text {cat }}\right)$, and $[\mathrm{ACTZ}]$ is the concentration of acetazolamide.

The values of the specificity constant $\left(k_{s}\right)$ (Petsko, 1999) and the heterogeneous constant $\left(k_{e}^{\prime}\right)$ were calculated using Eqs. (10) and (11), respectively, for each method.

$k_{s}=\frac{k_{c a t}}{K_{M}^{a p p}}$

$k_{e}^{\prime}=\frac{k_{c a t} \Gamma}{K_{M}^{a p p}}$

Plots were constructed of $I_{p a}^{-1}$ against $[\mathrm{ACTZ}]^{-1}$ (LineweaverBurke), $\quad I_{p a} \cdot[\text { ACTZ }]^{-1}$ versus $I_{p a} \quad$ (Eadie-Hofstee) and $[\mathrm{ACTZ}] \cdot \mathrm{Ipa}_{\text {pa }}^{-1}$ versus [ACTZ] (Hanes-Woolf) (Supplementary material).
The kinetic results obtained are listed in Table 2 .

As can be seen, the Michaelis-Menten kinetic parameters calculated using the different methods were all of the same order. The apparent Michaelis-Menten constant is related to the affinity of the bio-inspired complex for the substrate (ACTZ), as well as its concentration required for effective catalysis. The results obtained for this parameter showed a very small difference $(\Delta=0.093)$ between the methods and low values of $K_{M}^{a p p}$, indicating that the oxomanganese-phenanthroline complex had a high capacity for ACTZ oxidation. The catalytic constant describes the time required by the biomimetic complex to process one substrate molecule, and the $k_{\text {cat }}$ values obtained here reflected high and rapid catalytic activity. The specificity constant can be used to evaluate the relative reaction rates of the substrate during its catalytic transformation by the electroactive material. The heterogeneous reaction constants indicated that the electrocatalytic mechanism of the bioinspired sensor was dependent on the concentration of ACTZ adsorbed on the electrode surface, analogous to systems with electron mediation mechanisms (Aulenta et al., 2009; Klink et al., 2011; Palys et al., 2007).

\subsection{Sensor application using synthetic biological samples}

The proposed sensor was tested for the determination of ACTZ in synthetic samples of biological fluids (plasma, saliva, and urine) spiked with ACTZ (Supplementary material). Cyclic voltammetry was performed using the multiple standard additions method, with subsequent calculation of the recoveries (Supplementary material). The results demonstrated the viability of the bio-inspired sensor for the detection and quantification of ACTZ in the synthetic samples, with maximum recovery errors of $-4.3 \%$ for plasma, $+2.0 \%$ for saliva, and $+0.33 \%$ for urine. Application of the $t$-test confirmed that there were no significant differences between the theoretical and measured values (95\% confidence level), indicating that the proposed method could be applied to the analysis of real samples with different matrices.

\subsection{Doping control analysis of ACTZ in human urine}

The purpose of this experiment was to compare the 
experimental values with the minimum required performance level (MRPL) established by the WADA. For the detection of diuretics in urine in sports doping tests, the WADA requires that accredited laboratories achieve a minimum performance level of $200 \mathrm{ng} \mathrm{mL}^{-1}$ (WADA, 2014b). Although diuretics vary in terms of their potency, metabolism, and elimination (Cadwallader et al., 2010), resulting in different levels in urine, a concentration of $200 \mathrm{ng} \mathrm{mL} \mathrm{m}^{-1}\left(0.899 \mu \mathrm{mol} \mathrm{L}^{-1}\right)$ is sufficient for classification as abusive use of diuretics (doping).

The values of the anodic peak currents were obtained from the voltammograms and the analytical curve was constructed from the multiple standard additions (Supplementary material). The concentration of ACTZ in the urine sample was $5.05 \times 105 \mathrm{ng} \mathrm{mL}^{-1}$ $\left(2.27 \mathrm{mmol} \mathrm{L}^{-1}\right)$, so the result was positive, as expected. Confirmation of the positive result was performed in a similar way by counterproof analysis, which gave a value of $4.77 \times 105 \mathrm{ng} \mathrm{mL}^{-1}$ $\left(2.14 \mathrm{mmol} \mathrm{L}^{-1}\right)$ of ACTZ. There was a relatively small difference of $5.5 \%$ between the two values, confirming the positive result obtained for doping with ACTZ.

\section{Conclusions}

The electrochemical bio-inspired sensor based on the oxomanganese-phenanthroline complex showed catalytic properties in the electrooxidation of acetazolamide. The sensor provided high sensitivity, enabling the detection of low concentrations of ACTZ, and exhibited biomimetic characteristics, which were investigated using the Michaelis-Menten model. The applicability of the technique for the determination of acetazolamide in real samples was evaluated using three different synthetic biological fluids (plasma, saliva, and urine). Doping control analysis of ACTZ in a real urine sample confirmed the viability of the bio-inspired sensor as a new and promising platform for this type of analysis. The same electrode surface could be used for more than 500 separate determinations.

\section{Acknowledgment}

The authors are grateful for the financial support provided by CNPq (2005/01296-4 and 302728/2012-0) and FAPESP (scholarship awarded to WBSM process 2013/10469-6). The authors also thank SJT..:

\section{Appendix A. Supplementary material}

Supplementary data associated with this article can be found in the online version at http://dx.doi.org/10.1016/j.bios.2015.12.026.

\section{References}

International Standard for Testing. 2012. World Anti-doping Agency Code (WADA) Montreal.

The 2014 prohibited list - International Standard. 2014a. World Anti-doping Agency Code (WADA), Montreal.

Technical Document for Minimum Required Performance Levels for the Detection of Prohibited Substances. 2014b. World Anti-doping Agency Code (WADA), Montreal.

Almeida, M.G.J., Teixeira, M.F.S., Gomes, H.M., 2013. Spectrophotometric determination of acetazolamide using a flow injection system with $\mathrm{KMnO}_{4}$ reagent Braz. J. Anal. Chem. 9, 374-379.

Aulenta, F. Canosa, A., De Roma, L., Reale, P., Panero, S., Rossetti, S., Majone, M., 2009. Influence of mediator immobilization on the electrochemically assisted microbial dechlorination of trichloroethene (TCE) and cis-dichloroethene (cis DCE). J. Chem. Technol. Biotechnol. 84 (6), 864-870.

Aurora, R.N., Chowdhuri, S., Ramar, K., Bista, S.R., Casey, K.R., Lamm, C.I., Kristo, D.A.
Mallea, J.M., Rowley, J.A., Zak, R.S., Tracy, S.L., 2012. The treatment of central sleep Apnea syndromes in adults: practice parameters with an evidence-based literature review and meta-analyses. Sleep 35 (1), 17-40.

Bard, A.J., Faulkner, L.R., 2001. Electrochemical Methods: Fundamentals and Applications, 2nd ed. Wiley, New York.

Boni, A.C., Sotomayor, M.D.P.T., Lanza, M.R.V., Tanaka, S.M.C.N., Tanaka, A.A., 2010. Application of a biomimetic sensor based on iron phthalocyanine chloride: 4-methylbenzylidene-camphor detection. J. Braz. Chem. Soc. 21 (7), 1377-1383.

Brayfield, A., 2014. Martindale: The Complete Drug Reference, 38 ed. Pharmaceutical Press, London.

Cadwallader, A.B., de la Torre, X., Tieri, A., Botre, F., 2010. The abuse of diuretics as performance-enhancing drugs and masking agents in sport doping: pharmacology, toxicology and analysis. Br. J. Pharmacol. 161 (1), 1-16.

Chapron, D.J., White, L.B., 1984. Determination of acetazolamide in biological-fluids by reverse-phase high-performance liquid-chromatography. J. Pharm. Sci. 73 (7), 985-989.

Christou, G., 1989. Manganese carboxylate chemistry and its biological relevance. Acc. Chem. Res. 22 (9), 328-335.

Debalugera, Z.G., Goicolea, M.A., Barrio, R.J., 1994. Joint determination of todralazine and acetazolamide in human serum by differential-pulse polarography. J. Pharm. Biomed. 12 (7), 883-887.

Fogg, A.G., Ghawji, A.B., 1988. Reductive amperometric determination of nitrofurantoin and acetazolamide at a sessile mercury drop electrode using flow-injection analysis. Analyst 113 (5), 727-730.

Franzoi, A.C., Peralta, R.A., Neves, A., Vieira, I.C., 2009. Biomimetic sensor based on (MnMnII)-Mn-III complex as manganese peroxidase mimetic for determination of rutin. Talanta 78 (1), 221-226.

Fraser, A.D., 2004. Doping control from a global and national perspective. Ther Drug. Monit. 26 (2), 171-174.

Gholivand, M.B., Parvin, M.H., 2011. Voltammetric study of acetazolamide and its determination in human serum and urine using carbon paste electrode modified by gold nanoparticle. J. Electroanal. Chem. 660 (1), 163-168.

Greene, I.M., Kenny, A.D., 1992. Determination of acetazolamide in human serum by enzymatic assay. J. Pharmacol. Toxicol. 28 (3), 159-166.

Ichikawa, N., Naora, K., Hirano, H., Iwamoto, K., 1998. Quantitation of acetazolamide in rat plasma, brain tissue and cerebrospinal fluid by high-performance liquid chromatography. J. Pharm. Biomed. 17 (8), 1415-1421.

Jeronimo, P.C.A., Araujo, A.N., Conceicao, M., Montenegro, B.S.M., Satinsky, D., Solich, P., 2005. Flow-through sol-gel optical biosensor for the colorimetric determination of acetazolamide. Analyst 130 (8), 1190-1197.

Kaur, I.P., Smitha, R., Aggarwal, D., Kapil, M., 2002. Acetazolamide: future perspective in topical glaucoma therapeutics. Int. J. Pharm. 248 (1-2), 1-14.

Khamis, E.F., Abdelhamid, M., Hassan, E.M., Eshra, A., Elsayed, M.A., 1993. A stability-indicating 1st-derivative spectrophotometric assay of acetazolamide and its use in dissolution and kinetic-studies. J. Clin. Pharm. Ther. 18 (2), 97-101.

Khodadadian, M., Ahmadi, F., 2010. Computer-assisted design and synthesis of molecularly imprinted polymers for selective extraction of acetazolamide from human plasma prior to its voltammetric determination. Talanta 81 (4-5) 1446-1453.

Klink, M.J., Iwuoha, E.I., Ebenso, E.E., 2011. The electro-catalytic and redox-mediator effects of nanostructured PDMA-PSA modified-electrodes as phenol derivative sensors. Int. J. Electrochem. Sci. 6 (7), 2429-2442.

Laube, N., Mohr, B., Hesse, A., 2001. Laser-probe-based investigation of the evolution of particle size distributions of calcium oxalate particles formed in artificial urines. J. Cryst. Growth 233 (1-2), 367-374.

Liu, L., Qiu, C.L., Chen, Q., Zhang, S.M., 2006. Corrosion behavior of Zr-based bulk metallic glasses in different artificial body fluids. J. Alloy. Compd. 425 (1-2), 268-273.

Low, E.V., Avery, A.J., Gupta, V., Schedlbauer, A., Grocott, M.P.W., 2012. Identifying the lowest effective dose of acetazolamide for the prophylaxis of acute mountain sickness: systematic review and meta-analysis. Br. Med. J. 345.

Lyons, M.E.G., Bannon, T., Hinds, G., Rebouillat, S., 1998. Reaction/diffusion with Michaelis-Menten kinetics in electroactive polymer films - Part 2. The transient amperometric response. Analyst 123 (10), 1947-1959.

Lyons, M.E.G., Fitzgerald, C.A., Smyth, M.R., 1994. Glucose-oxidation at ruthenium dioxide-based electrodes. Analyst 119 (5), 855-861.

Machini, W.B.S., Teixeira, M.F.S., 2014. Electrochemical properties of the oxo-manganese-phenanthroline complex immobilized on ion-exchange polymeric film and its application as biomimetic sensor for sulfite ions. Electroanalysis 26 (10), 2182-2190.

Machini, W.B.S., Teixeira, M.F.S., 2015. Application of oxo-manganese complex immobilized on ion-exchange polymeric film as biomimetic sensor for nitrite ions. Sens. Actuators B Chem. 217, 58-64.

Mazzoni, I., Barroso, O., Rabin, O., 2011. The list of prohibited substances and methods in sport: structure and review process by the world anti-doping agency. J. Anal. Toxicol. 35 (9), 608-612.

McNaught, A.D., Wilkinson, A., 1997. International Union of Pure and Applied Chemistry, 2nd ed. Blackwell Science, Oxford, Compendium of chemical terminology : IUPAC recommendations.

Meyer, T.J., Huynh, M.H.V., Thorp, H.H., 2007. The possible role of proton-coupled electron transfer (PCET) in water oxidation by photosystem II. Angew. Chem. Int. Ed, 46 (28), 5284-5304.

Moratal, J.M., Martinezferrer, M.J., Jimenez, H.R., Donaire, A., Castells, J., Salgado, J., 1992. 1H NMR and UV-vis spectroscopic characterization of sulfonamide complexes of nickel(II)-carbonic anhydrase - resonance assignments based on NOE effects. J. Inorg. Biochem. 45 (4), 231-243. 
Palys, B., Bokun, A., Rogalski, J., 2007. Poly-o-phenylenediamine as redox mediator for laccase. Electrochim. Acta 52 (24), 7075-7082.

Pecoraro, V.L., Baldwin, M.J., Gelasco, A., 1994. Interaction of manganese with dioxygen and its reduced derivatives. Chem. Rev. 94 (3), 807-826.

Petsko, G.A., 1999. Structure and mechanism in protein science: a guide to enzyme catalysis and protein folding. Nature 401 (6749), 115-116.

Rebilly, J.N., Colasson, B., Bistri, O., Over, D., Reinaud, O., 2015. Biomimetic cavitybased metal complexes. Chem. Soc. Rev. 44 (2), 467-489.

Reiss, W.G., Oles, K.S., 1996. Acetazolamide in the treatment of seizures. Ann. Pharmacother. 30 (5), 514-519.

Renger, G., 1987. Biological exploitation of solar-energy by photosynthetic water splitting. Angew. Chem. Int. Ed. 26 (7), 643-660.

Rivalta, I., Brudvig, G.W., Batista, V.S., 2012. Oxomanganese complexes for natural and artificial photosynthesis. Curr. Opin. Chem. Biol. 16 (1-2), 11-18.

Ruy, M.R.D., Figueira, E.C., Sotomayor, M.D.T., 2014. Electroanalytical determination of bumetanide employing a biomimetic sensor for detection of doping in sports. Anal. Methods 6 (15), 5792-5798.

Santos, W.D.R., Sousa, A.L., Sotomayor, M.D.T., Damos, F.S., Tanaka, S.M.C.N., Kubota, L.T., Tanaka, A.A., 2009. Manganese phthalocyanine as a biomimetic electrocatalyst for phenols in the development of an amperometric sensor. J. Braz. Chem. Soc. 20 (6), 1180-1187.

Shakibaian, V., Parvin, M.H., 2012. Determination of acetazolamide by graphene paste electrode. J. Electroanal. Chem. 683, 119-124.

Sproviero, E.M., Gascon, J.A., McEvoy, J.P., Brudvig, G.W., Batista, V.S., 2006. Characterization of synthetic oxomanganese complexes and the inorganic core of the O-2-evolving complex in photosystem - II: evaluation of the DFT/B3LYP level of theory. J. Inorg. Biochem. 100 (4), 786-800.

Svancara, I., Vytras, K., Kalcher, K., Walcarius, A., Wang, J., 2009. Carbon paste electrodes in facts, numbers, and notes: a review on the occasion of the 50years jubilee of carbon paste in electrochemistry and electroanalysis. Electroanalysis 21 (1), 7-28.

Walash, M.I., El-Brashy, A., El-Enany, N., Wahba, M.E., 2010. Validated stability indicating spectrophotometric method for the determination of acetazolamide in dosage forms through complex formation with palladium (II). Int. J. Biomed. Sci. 6 (2), 141-149.

Wall, M., McDermott, M.P., Kieburtz, K.D., Corbett, J.J., Feldon, S.E., Friedman, D.I, Katz, D.M., Keltner, J.L., Schron, E.B., Kupersmith, M.J., Intracranial, N.I., 2014. Effect of acetazolamide on visual function in patients with idiopathic intracranial hypertension and mild visual loss: the idiopathic intracranial hypertension treatment trial. J. Am. Med. Assoc. 311 (16), 1641-1651.

Wallace, S.M., Shah, V.P., Riegelman, S., 1977. GLC analysis of acetazolamide in blood, plasma, and saliva following oral-administration to normal subjects. J. Pharm. Sci. 66 (4), 527-530.

Wieghardt, K., 1989. The active-sites in manganese-containing metalloproteins and inorganic model complexes. Angew. Chem. Int. Ed. 28 (9), 1153-1172.

Wieghardt, K., 1994. A structural model for the water-oxidizing manganese cluster in photosystem-II. Angew. Chem. Int. Ed. 33 (7), 725-728.

Zarghi, A., Shafaati, A., 2002. Rapid determination of acetazolamide in human plasma. J. Pharm. Biomed. 28 (1), 169-172. 